\title{
Analysis of the Inhibitory Elements in the p5 Peptide Fragment of the CDK5 Activator, p35, CDKR1 Protein
}

\author{
B.K. Binukumar ${ }^{\mathrm{a}}$, Varsha Shukla ${ }^{\mathrm{a}}$, Niranjana D. Amin ${ }^{\mathrm{a}}$, Manju Bhaskar ${ }^{\mathrm{a}}$, Suzanne Skuntz $^{\mathrm{a}}$, \\ Joseph Steiner ${ }^{\mathrm{a}}$, Dirk Winkler ${ }^{\mathrm{b}}$, Steven L. Pelech ${ }^{\mathrm{b}}$ and Harish C. Pant ${ }^{\mathrm{a}, *}$ \\ ${ }^{\mathrm{a}}$ National Institute of Neurological Disorders and Strokes, National Institutes of Health, Bethesda, MD, USA \\ ${ }^{\mathrm{b}}$ Kinexus Bioinformatics Corporation, and Division of Neurology, Department of Medicine, University of British \\ Columbia, BC, Canada
}

Accepted 14 July 2015

\begin{abstract}
Besides the hallmark pathology of amyloid plaques and neurofibrillary tangles, it is well documented that cyclindependent kinase 5 (CDK5), a critical neuronal protein kinase in nervous system development, function, and survival, when deregulated and hyperactivated induces Alzheimer's disease (AD) and amyotrophic lateral sclerosis and Parkinson's disease-like phenotypes in mice. In a recent study, we demonstrated that p5, a small, truncated fragment of 24 amino acid residues derived from the CDK5 activator protein 35 (NCK5A, p35), selectively inhibited deregulated CDK5 hyperactivity and ameliorated AD phenotypes in model mice. In this study, we identified the most inhibitory elements in the p5 peptide fragment. Each amino acid residue in $\mathrm{p} 5$ was systematically replaced with its homologous residues that may still be able to functionally substitute. The effects of these $\mathrm{p} 5$ peptide analogs were studied on the phosphotransferase activities of CDK5/p35, CDK5/p25, ERK1, and GSK3 $\beta$. The mimetic 55 peptide (A/V substitution at the C-terminus of the peptide) in the sequence, KNAFYERALSIINLMTSKMVQINV (p5-MT) was the most effective inhibitor of CDK5 kinase activity of 79 tested mimetic peptides including the original p5 peptide, KEAFWDRCLSVINLMSSKMLQINA (p5-WT). Replacement of the residues in C-terminus end of the peptide affected CDK5 phosphotransferase activity most significantly. These peptides were strong inhibitors of CDK5, but not the related proline-directed kinases, ERK1 and GSK3 $\beta$.
\end{abstract}

Keywords: Alzheimer's disease, CDK5 activator protein 35, cyclin-dependent kinase 5, phosphorylation

\section{INTRODUCTION}

Phosphorylation of neuronal cytoskeletal proteins is topographically and stably regulated during nervous system development and function. Although protein kinases substrates and regulators are synthesized in the soma, phosphorylation of cytoskeletal proteins such as neurofilaments is consigned to axons [1-4]. While studying the protein kinases involved in

\footnotetext{
${ }^{*}$ Correspondence to: Dr. Harish C. Pant, Laboratory of Neuronal Cytoskeletal Protein Regulation Section, National Institute of Neurological Disorders and Stroke, National Institutes of Health, Bethesda, 20892 MD, USA. Tel.: +1 301402 2124; Fax: +1 301496 1339; E-mail: PantH@ninds.nih.gov.
}

compartment-specific phosphorylation in neurons, we identified the cell cycle-like kinase, cyclin-dependent kinase 5 (CDK5), as a major kinase responsible for the phosphorylation of proline- directed Ser/Thr repeats in the $\mathrm{C}$ - terminus tail domains of human neurofilament proteins [5]. CDK5 is unique among the CDK family of protein kinases; its activity is primarily restricted to neuronal cells due to its neuron specific activators CDKR1 (also known as p35) and CDKR2 (also known as p39). CDK5 is a multifunctional kinase that targets more than a hundred proteins including other protein kinases and phosphatases essential to neuronal development, function, and survival $[2,6-8]$. 
In recent years, we and others have shown that CDK5 is deregulated and hyperactivated in the brains of patients expressing several neurodegenerative disorders such as Alzheimer's disease (AD) and amyotrophic lateral sclerosis (ALS) [9-13]. A hypothesis has been proposed that CDK5 deregulation arises in stressed neurons (oxidative, amyloid- $\beta$, glutamate excitotoxic, or inflammatory), accompanied by increase in $\mathrm{Ca}^{+2}$ influx, calpain activation followed by proteolytic cleavage of the $\mathrm{p} 35$ activator into a p10 Nterminal fragment and a p25 hyperactivator that stably binds and hyperactivates CDK5 in a CDK5/p25 complex [13-17]. Such complexes have been detected in AD brains, and they may contribute, in part, to the formation of the hyperphosphorylated neurofilament and tau tangles, and the appearance of amyloid plaques and neuronal apoptosis, all of which are hallmarks of $\mathrm{AD}$ pathology. Accordingly, CDK5/p25 has been identified as a potential therapeutic target for $\mathrm{AD}$ and other neurodegenerative disorders that share a similar pattern of CDK5 hyperactivation [17].

Currently, most therapeutic approaches that target the deregulated CDK5/p25 complex have focused primarily on drugs like Roscovitine that inhibit by interfering with the ATP binding domain of CDK5 [18-20]. These drugs, however, lack specificity, since all kinases including cell cycle CDKs, are vulnerable at the ATP binding site. During the course of our studies on the basis of CDK5/p25 crystal structure, the amino acid residues interacting between CDK5 and p25 chains within 3.5 Angstroms were identified (unpublished data). This analysis identified two peptides derived as truncations of the p35 regulator, a larger 126 amino acid fragment (CIP) and a shorter 24 amino acid peptide (p5). In vitro, these peptides inhibited CDK5/p35 and CDK5/p25, respectively, whereas in rodent cortical neurons, only the deregulated CDK5/p25 was specifically inhibited without affecting the endogenous CDK5/p35 activity [21]. We considered these peptides as potential therapeutic candidates for rescuing neurodegenerative disorders in model mice that share the hyperactivated CDK5-induced phenotypes.

In a recent study we demonstrated $\mathrm{p} 5$ has a higher inhibitory activity compared to CIP. In the present study, to further understand p5's inhibitory role, we undertook the synthesis of analogues of the parent peptide p5-WT (KEAFWDRCLSVINLMSSKMLQINA) in which each amino acid was individually replaced with homologous residues that may still be able to functionally substitute. This analysis generated 78 mimetic peptides. The effects of these peptides on recombinant human $\mathrm{CDK} 5 / \mathrm{p} 25$ phosphotransferase activity were evaluated. In addition to CDK5/p25, the actions of these p5 peptide analogs on the phosphotransferase activities of CDK5/p35, ERK1, and GSK3 $\beta$ were also measured. From these studies, we identified a mimetic p5 peptide, KNAFYERALSIINLMTSKMVQINV (p5-MT), that may feature sufficiently distinct epitopes such that it would not be recognized by antibodies that would react with endogenous p35 and its proteolytic fragments. In addition, p5-MT showed more potent inhibitory activity toward CDK5 compared to p5-WT.

\section{MATERIALS AND METHODS}

\section{Quality control and reagents}

The various recombinant protein kinase targets employed in the target profiling process were sourced from Signal Chem Pharmaceuticals, Inc. (Richmond, BC, Canada). Quality control testing was routinely performed on each of the protein kinase targets to ensure compliance to acceptable standards. $\left[\gamma-{ }^{33} \mathrm{P}\right]$ ATP was purchased from PerkinElmer.

Both enzymes (CDK5/p25 and CDK5/p35) were coexpressed together by baculovirus in Sf9 insect cells using an N-terminal GST tag and purified. Since they were co-expressed together, they were added to the reaction mixture as CDK5/p25 and CDK5/p35 complexes at the same time. The assay conditions for protein kinases were optimized to yield acceptable enzymatic activity. In addition, the assays were optimized to give a high signal-to-noise ratio.

\section{Protein kinase assays}

A radioisotope assay format was used for profiling an evaluation of the kinase under investigation and all assays were performed in a designated radioactive working area. Protein kinase assays were carried out at $30^{\circ} \mathrm{C}$ for $20 \mathrm{~min}$ in a final volume of $25 \mu \mathrm{l}$ according to the following assay reaction recipe:

Set 1:

Component 1. $5 \mu$ l of diluted active CDK5/p35 and CDK5/p25 (final assay concentrations of 14 and $15 \mathrm{nM}$, respectively).

Component $2.5 \mu \mathrm{l}$ of assay solution of calf thymus histone $\mathrm{H} 1$ (final assay concentration $1 \mathrm{mg} / \mathrm{ml}$ ).

Component 3. $5 \mu$ l of kinase assay buffer (concentrations: $25 \mathrm{mM}$ MOPS, $\mathrm{pH} 7.2,12.5 \mathrm{mM} \beta$ glycerophosphate, $25 \mathrm{mM} \mathrm{MgCl}_{2}, 5 \mathrm{mM}$ EGTA, $2 \mathrm{mM}$ EDTA and $0.25 \mathrm{mM}$ dithiothreitol). 
Component 4. $5 \mu \mathrm{l}$ of $\left[\gamma^{-33} \mathrm{P}\right] \mathrm{ATP}(250 \mu \mathrm{M}$ stock solution, $0.8 \mu \mathrm{Ci}$ ).

Component 5. $5 \mu \mathrm{l}$ of p5 (p5-WT) or p5-MT (p5 A/V) peptide.

Set 2:

Components 1-4 were same as in Set 1 .

Component $5.5 \mu$ l of peptide inhibitor (various concentrations) or $10 \%$ DMSO.

Each assay was initiated by the addition of $\left[\gamma-{ }^{33} \mathrm{P}\right]$ and, after $20 \mathrm{~min}$ incubation, was terminated by spotting $10 \mu l$ of the reaction mixture onto Multi screen phosphocellulose P81 plate. The Multi screen phosphocellulose P81 plate was washed 3 times for approximately $15 \mathrm{~min}$ each time in a $1 \%$ phosphoric acid solution. The radioactivity on the P81 plate was counted in the presence of scintillation fluid in a Trilux scintillation counter. Blank control was set up which included all the assay components except the addition of the appropriate substrate (replaced with equal volume of assay dilution buffer). The corrected activity for protein kinase was determined by removing the blank control value. Each experiment was repeated twice in duplicate.

All other materials were of standard laboratory grade. The 79 peptides analogs were produced by SPOT synthesis as large spots and were based on a selected substitution analysis based on the original sequence KEAFWDRCLSVINLMSSKMLQINA and shown in Supplementary Table 1.

\section{RESULTS AND DISCUSSION}

By systematic alteration of each amino acid residue in the parent peptide sequence with a homologous amino acid residue, it should be possible to identify the most crucial amino acid positions. It may be feasible to even identify amino acids that may improve the binding of $\mathrm{p} 5$ analogues to CDK5. These are mimetic substitutions that preserve and may improve upon the inhibitory activity of the $\mathrm{p} 5$ peptide toward CDK5.

Furthermore, the resulting analogues may also be immunologically distinct, which could foster their differentiation from endogenous p35 and its derivatives with antibodies. The actual sequence of p5 cannot be used to create an immunizing peptide that can distinguish between p5 and a shorter peptide with the same sequence. By identifying the most critical amino acids for inhibition, a modified inhibitory peptide may be created to elicit antibodies that could be used to track its distribution in the brain in future immunohistochemistry experiments.
SPOT synthesis of $\mathrm{p} 5$ peptide analogues was undertaken as the method of choice for this purpose as it would be the most cost-effective way to identify the critical amino acid residues in $\mathrm{p} 5$ that permit it to compete with p25 and/or p35 and inhibit CDK5 more effectively. As shown in Supplementary Tables 1 and 2, using the 78 mimetic peptides of p5, our studies revealed that the most critical amino acid residues for the inhibitory effect of p5 on CDK5/p25 were located in the last four amino acids in the p5 parent peptide (QINA). Replacement of A to V and M (A/V, $\mathrm{M})$ provided for the most effective inhibitory residues substitutions. Conversely, substitution of Q to N, E, or $\mathrm{D}$ were the most stimulatory replacements, increasing activity by almost $80 \%$. Equivalent stimulation is seen in the replacement of I to $\mathrm{G}$, and $\mathrm{N}$ to $\mathrm{G}, \mathrm{E}$, or D.

The initial aim of these experiments was to determine which of the various peptides tested exhibited reduced inhibitory activity so as to identify the most critical amino acids for the interaction. It was also interesting to define replacement amino acids that could inhibit the phosphotransferase activity of CDK5/p25 better than the original peptide p5-WT (sequence KEAFWDRCLSVINLMSSKMLQINA; Peptide-1).

The phosphotransferase activity of CKD5/p25 protein kinase in the presence of each of the 79 peptides listed in Table 1 was assayed by employing the standardized radioactive assay methodology as described in Materials and Methods. The results observed as activity (cpm) are presented in Supplementary Tables 1 and 2 . The intra-assay variability was determined to be less than $10 \%$.

The profiling data for the 79 inhibitory peptides assayed against CDK5/p25 in Table 1 are arranged based on lowest to highest counts per minute (cpm). The $\%$ Activity and \% Change from Control (CFC) values were determined using the original Peptide-1 (sequence KEAFWDRCLSVINLMSSKMLQINA) as the control (100\%) and measuring all other counts relative to this. With this method, only four peptides were identified that yielded lower counts against CDK5/p25 than the original peptide sequence. Peptides- 77 and 78 showed the most inhibition of CDK5/p25 compared to the control p5-WT peptide, at -26 and $-25 \%$, respectively. Peptides- 15 and 76 also showed moderate reductions of -8 and $-7 \%$. Most of the other peptides gave higher counts $(\mathrm{cpm})$ ranging from +0 to $+79 \%$ greater than observed with the parent p5 peptide with the histone $\mathrm{H} 1$ substrate. The four peptides that gave the highest counts were Peptides-26, 62, 64, and 70. The altered amino acids 
Table 1

$\%$ Activity of CDK5/p25 in the presence of inhibitory peptides using radiometric assay method arranged from lowest to highest counts (cpm), with two independent experiments in duplicates. Each assay solution contained 10\% DMSO; The blank control without histone was 1,217 cpm, and with histone was $202,940 \mathrm{cpm}$. The $\mathrm{cpm}$ values given in the table was subtracted for the blank with histone in the presence of different peptides. The cpm value in the presence of the p5-WT peptide (\#1) was taken as $100 \%$ phosphotransferase activity. The negative numbers in the percent change from control $(\% \mathrm{CFC}$ ) values correspond to even greater inhibition and positive numbers are less inhibition in the CDK5 phosphotransferase activity relative to the p5- WT peptide

\begin{tabular}{|c|c|c|c|c|}
\hline Peptide ID & Peptide Sequence & CPM & $\%$ Activity & $\% \mathrm{CFC}$ \\
\hline 78 & KEAFWDRCLSVINLMSSKMLQINM & 89762 & 74 & -26 \\
\hline 77 & KEAFWDRCLSVINLMSSKMLQINV & 90305 & 75 & -25 \\
\hline 15 & KEAFYDRCLSVINLMSSKMLQINA & 111665 & 92 & -8 \\
\hline 76 & KEAFWDRCLSVINLMSSKMLQINL & 113022 & 93 & -7 \\
\hline 1 & KEAFWDRCLSVINLMSSKMLQINA & 121167 & 100 & 0 \\
\hline 20 & KEAFWDRALSVINLMSSKMLQINA & 121639 & 100 & 0 \\
\hline 4 & KNAFWDRCLSVINLMSSKMLQINA & 122973 & 101 & 1 \\
\hline 33 & KEAFWDRCLSIINLMSSKMLQINA & 123757 & 102 & 2 \\
\hline 48 & KEAFWDRCLSVINLMTSKMLQINA & 126451 & 104 & 4 \\
\hline 79 & KEAFWDRCLSVINLMSSKMLQINS & 131811 & 109 & 9 \\
\hline 16 & KEAFWERCLSVINLMSSKMLQINA & 135248 & 112 & 12 \\
\hline 75 & KEAFWDRCLSVINLMSSKMLQINI & 138095 & 114 & 14 \\
\hline 14 & KEAFFDRCLSVINLMSSKMLQINA & 141068 & 116 & 16 \\
\hline 29 & KEAFWDRCLMVINLMSSKMLQINA & 141207 & 117 & 17 \\
\hline 28 & KEAFWDRCLYVINLMSSKMLQINA & 141312 & 117 & 17 \\
\hline 61 & KEAFWDRCLSVINLMSSKMVQINA & 141773 & 117 & 17 \\
\hline 41 & KEAFWDRCLSVINIMSSKMLQINA & 142416 & 118 & 18 \\
\hline 42 & KEAFWDRCLSVINVMSSKMLQINA & 145310 & 120 & 20 \\
\hline 3 & KDAFWDRCLSVINLMSSKMLQINA & 145721 & 120 & 20 \\
\hline 18 & KEAFWNRCLSVINLMSSKMLQINA & 149428 & 123 & 23 \\
\hline 59 & KEAFWDRCLSVINLMSSKCLQINA & 150317 & 124 & 24 \\
\hline 17 & KEAFWQRCLSVINLMSSKMLQINA & 151097 & 125 & 25 \\
\hline 34 & KEAFWDRCLSVLNLMSSKMLQINA & 151937 & 125 & 25 \\
\hline 13 & KEAWWDRCLSVINLMSSKMLQINA & 152154 & 126 & 26 \\
\hline 53 & KEAFWDRCLSVINLMSYKMLQINA & 152906 & 126 & 26 \\
\hline 38 & KEAFWDRCLSVIQLMSSKMLQINA & 154117 & 127 & 27 \\
\hline 50 & KEAFWDRCLSVINLMASKMLQINA & 154975 & 128 & 28 \\
\hline 2 & REAFWDRCLSVINLMSSKMLQINA & 155431 & 128 & 28 \\
\hline 25 & KEAFWDRCGSVINLMSSKMLQINA & 155679 & 128 & 28 \\
\hline 56 & KEAFWDRCLSVINLMSSRMLQINA & 155892 & 129 & 29 \\
\hline 49 & KEAFWDRCLSVINLMYSKMLQINA & 156497 & 129 & 29 \\
\hline 67 & KEAFWDRCLSVINLMSSKMLQLNA & 156827 & 129 & 29 \\
\hline 11 & KESFWDRCLSVINLMSSKMLQINA & 163262 & 135 & 35 \\
\hline 37 & KEAFWDRCLSVGNLMSSKMLQINA & 164154 & 135 & 35 \\
\hline 22 & KEAFWDRCISVINLMSSKMLQINA & 165242 & 136 & 36 \\
\hline 19 & KEAFWDKCLSVINLMSSKMLQINA & 166245 & 137 & 37 \\
\hline 8 & KEIFWDRCLSVINLMSSKMLQINA & 166249 & 137 & 37 \\
\hline 63 & KEAFWDRCLSVINLMSSKMGQINA & 166937 & 138 & 38 \\
\hline 74 & KEAFWDRCLSVINLMSSKMLQING & 167174 & 138 & 38 \\
\hline 5 & KQAFWDRCLSVINLMSSKMLQINA & 167318 & 138 & 38 \\
\hline 68 & KEAFWDRCLSVINLMSSKMLQVNA & 167911 & 139 & 39 \\
\hline 10 & KEMFWDRCLSVINLMSSKMLQINA & 168848 & 139 & 39 \\
\hline 58 & KEAFWDRCLSVINLMSSKALQINA & 170159 & 140 & 40 \\
\hline 55 & KEAFWDRCLSVINLMSMKMLQINA & 170786 & 141 & 41 \\
\hline 12 & KEAYWDRCLSVINLMSSKMLQINA & 171316 & 141 & 41 \\
\hline 24 & KEAFWDRCASVINLMSSKMLQINA & 171581 & 142 & 42 \\
\hline 43 & KEAFWDRCLSVINAMSSKMLQINA & 172298 & 142 & 42 \\
\hline 51 & KEAFWDRCLSVINLMMSKMLQINA & 174387 & 144 & 44 \\
\hline 57 & KEAFWDRCLSVINLMSSKSLQINA & 175515 & 145 & 45 \\
\hline 9 & KEVFWDRCLSVINLMSSKMLQINA & 175785 & 145 & 45 \\
\hline 44 & KEAFWDRCLSVINGMSSKMLQINA & 176026 & 145 & 45 \\
\hline 69 & KEAFWDRCLSVINLMSSKMLQANA & 178232 & 147 & 47 \\
\hline 72 & KEAFWDRCLSVINLMSSKMLQIQA & 181214 & 150 & 50 \\
\hline 23 & KEAFWDRCVSVINLMSSKMLQINA & 181448 & 150 & 50 \\
\hline 45 & KEAFWDRCLSVINLSSSKMLQINA & 182017 & 150 & 50 \\
\hline
\end{tabular}


Table 1

(Continued)

\begin{tabular}{|c|c|c|c|c|}
\hline 30 & KEAFWDRCLSAINLMSSKMLQINA & 184482 & 152 & 52 \\
\hline 21 & KEAFWDRMLSVINLMSSKMLQINA & 185771 & 153 & 53 \\
\hline 36 & KEAFWDRCLSVANLMSSKMLQINA & 186090 & 154 & 54 \\
\hline 31 & KEAFWDRCLSGINLMSSKMLQINA & 186098 & 154 & 54 \\
\hline 6 & KEGFWDRCLSVINLMSSKMLQINA & 186614 & 154 & 54 \\
\hline 27 & KEAFWDRCLTVINLMSSKMLQINA & 189548 & 156 & 56 \\
\hline 7 & KELFWDRCLSVINLMSSKMLQINA & 190811 & 157 & 57 \\
\hline 47 & KEAFWDRCLSVINLCSSKMLQINA & 191850 & 158 & 58 \\
\hline 35 & KEAFWDRCLSVVNLMSSKMLQINA & 192606 & 159 & 59 \\
\hline 46 & KEAFWDRCLSVINLASSKMLQINA & 193507 & 160 & 60 \\
\hline 65 & KEAFWDRCLSVINLMSSKMLEINA & 194286 & 160 & 60 \\
\hline 54 & KEAFWDRCLSVINLMSAKMLQINA & 194650 & 161 & 61 \\
\hline 52 & KEAFWDRCLSVINLMSTKMLQINA & 195577 & 161 & 61 \\
\hline 60 & KEAFWDRCLSVINLMSSKMIQINA & 196418 & 162 & 62 \\
\hline 39 & KEAFWDRCLSVIELMSSKMLQINA & 196444 & 162 & 62 \\
\hline 73 & KEAFWDRCLSVINLMSSKMLQIEA & 197176 & 163 & 63 \\
\hline 32 & KEAFWDRCLSLINLMSSKMLQINA & 197903 & 163 & 63 \\
\hline 40 & KEAFWDRCLSVIDLMSSKMLQINA & 198851 & 164 & 64 \\
\hline 71 & KEAFWDRCLSVINLMSSKMLQIDA & 199652 & 165 & 65 \\
\hline 66 & KEAFWDRCLSVINLMSSKMLDINA & 199850 & 165 & 65 \\
\hline 62 & KEAFWDRCLSVINLMSSKMAQINA & 203269 & 168 & 68 \\
\hline 26 & KEAFWDRCLAVINLMSSKMLQINA & 204497 & 169 & 69 \\
\hline 70 & KEAFWDRCLSVINLMSSKMLQGNA & 207194 & 171 & 71 \\
\hline 64 & KEAFWDRCLSVINLMSSKMLNINA & 217093 & 179 & 79 \\
\hline
\end{tabular}

residues in these particular peptides were apparently the most critical for the CDK5 inhibitory activity of p5.

Figure 1 summarizes the findings from analysis of the inhibitory actions of the p5-WT mimetic peptide analogs on the CDK5 phosphotransferase activity. We conclude that the most critical amino acid residues for the inhibitory effect of p 25 fragment on CDK5 phosphotransferase activity in the presence of p25 activator appear to be: K1, A3, F4, R7, L9, S10, I12, N13, M15, S17, K18, M19, Q21, I22, and N23. These amino acid residues were distributed across the entire sequence, but region from residues 10 to 23 was the most essential for binding, whereas the last amino acid residue at Position 24 could be altered to actually improve the inhibitory activity of $\mathrm{p} 5$ peptide analogs. The most effective replacements of A at Position 24 were with the $\mathrm{M}$ and $\mathrm{V}$ amino acid residues (A24M and A24V). Most of the other amino acid residues replacements of the p5-WT sequence reduced the inhibitory effect of the peptide mimetics on p25-activated CDK5 phosphotransferase activity. The most marked losses of inhibitory activity were observed with the peptides with the S10A, N13D, L20A Q21N, I22G and N23D replacements.

The above experiments provided evidence that mimetic p5 (A/V) corresponding to Peptide-77 in Table 1 with the sequence KNAFYERALSIINLMTSKMVQINV (p5-MT) was one of the most effective inhibitors of CDK5 phosphotransferase activity of the 79 tested peptides. We next carried out a comparative study using the original wild-type p5 peptide corresponding to Peptide- 1 in Table 1 with the sequence KEAFWDRCLSVINLMSSKMLQINA (p5-WT) and the p5-MT peptide to ascertain their inhibitory effects on CDK5/p35, CDK5/p25, and two more related proline-directed protein-serine/threonine kinases, GSK3 $\beta$ and ERK1. The results observed as $\%$ change of phosphotransferase activity at different inhibitor concentrations are presented in Table 2, while Supplementary Tables 3-6 and 7-10 contains all the raw data for these protein kinase assays with the p5-WT and $55-\mathrm{MT}$ peptides, respectively. The intra-assay variability was determined to be less than $10 \%$. Inhibition of target phosphotransferase activity by the compound gave negative values, while activation of phosphotransferase target activity gave positive values. Only values of $>25 \%$ change were considered to be significant.

The profiling study for the parent peptide p5-WT against CDK5/p25 showed moderate to strong inhibition of CDK5/p25 phosphotransferase activity with increasing compound concentration (Supplementary Table 3). At $250 \mu \mathrm{M}$ concentration of this peptide, the CDK5/p25 phosphotransferase activity was inhibited by $59 \%$ compared to control. An $\mathrm{IC}_{50}$ value of $169 \mu \mathrm{M}$ was generated (using a graph of log inhibitor versus normalized response with variable slope with the Prism software) for this peptide against CDK5/p25 (Fig. 2). 


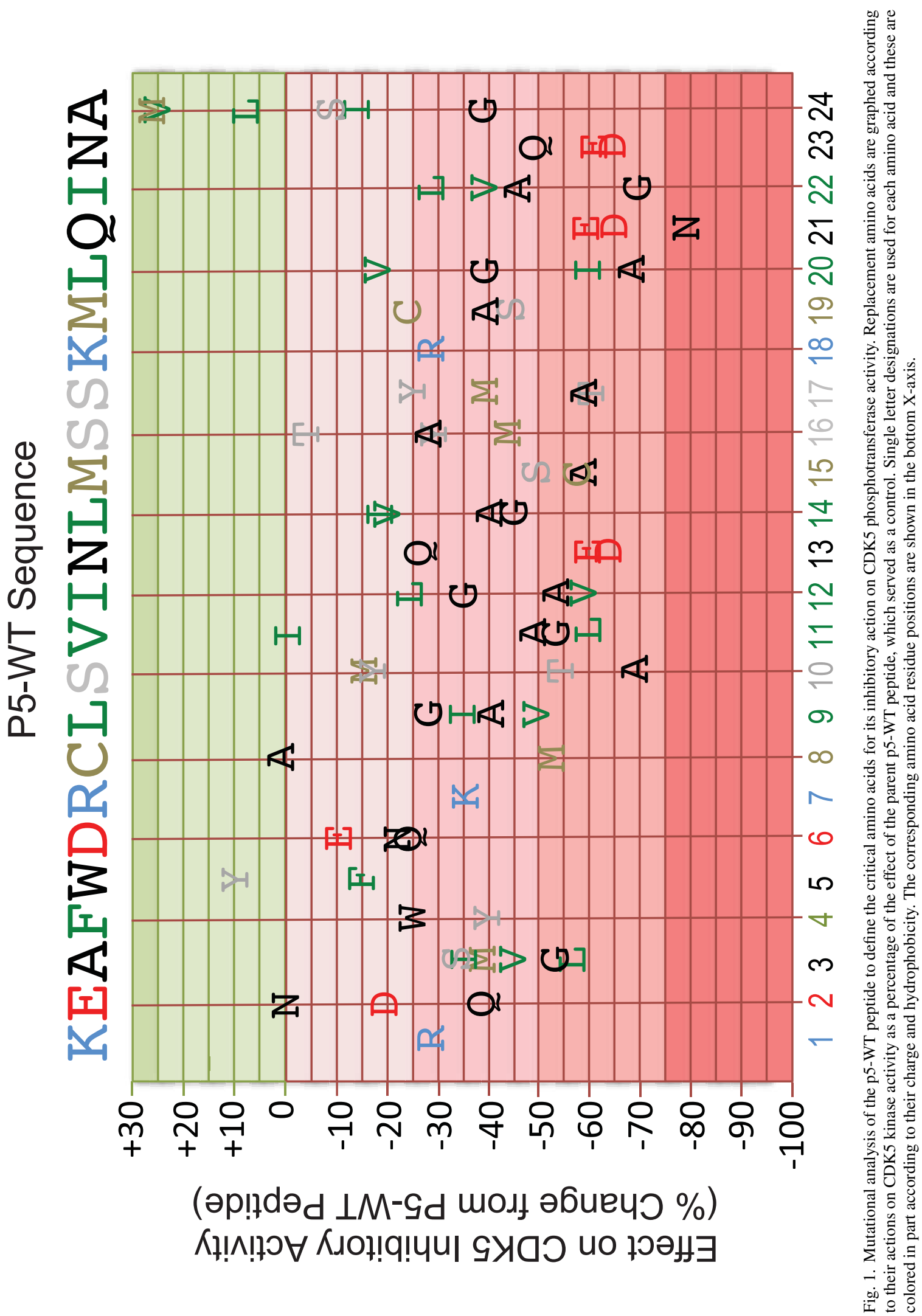


Table 2

Comparison of the p5-WT and p5-MT peptides for their inhibitory activities toward diverse proline-directed protein kinases. CDK5/p35, $\mathrm{CDK} 5 / \mathrm{p} 25$, and two more related proline-directed protein-serine/threonine kinases, GSK3 $\beta$ and ERK1, were tested in duplicate at six different concentrations of these peptides $(1$ to $500 \mu \mathrm{M})$ using a radiometric assay method to determine their $\mathrm{IC}_{50}$ values

\begin{tabular}{|c|c|c|c|c|c|c|}
\hline \multicolumn{7}{|c|}{ A. Peptide p5-WT } \\
\hline Target ID & $\begin{array}{c}\% \text { Activity } \\
\text { Change } \\
1 \mu \mathrm{M} \\
\end{array}$ & $\begin{array}{c}\% \text { Activity } \\
\text { Change } \\
10 \mu \mathrm{M} \\
\end{array}$ & $\begin{array}{c}\% \text { Activity } \\
\text { Change } \\
50 \mu \mathrm{M} \\
\end{array}$ & $\begin{array}{c}\% \text { Activity } \\
\text { Change } \\
100 \mu \mathrm{M}\end{array}$ & $\begin{array}{c}\% \text { Activity } \\
\text { Change } \\
250 \mu \mathrm{M} \\
\end{array}$ & $\begin{array}{c}\% \text { Activity } \\
\text { Change } \\
500 \mu \mathrm{M}\end{array}$ \\
\hline CDK5/p25 & 0 & -13 & -20 & -41 & -59 & -72 \\
\hline CDK5/p35 & 2 & -2 & -10 & -29 & -53 & -76 \\
\hline ERK1 & 0 & 0 & -3 & -6 & -11 & -25 \\
\hline GSK3 $\beta$ & -3 & -1 & 0 & 8 & 19 & 24 \\
\hline \multicolumn{7}{|c|}{ B. Peptide p5-MT } \\
\hline Target ID & $\begin{array}{c}\% \text { Activity } \\
\text { Change } \\
1 \mu \mathrm{M} \\
\end{array}$ & $\begin{array}{c}\% \text { Activity } \\
\text { Change } \\
10 \mu \mathrm{M} \\
\end{array}$ & $\begin{array}{c}\% \text { Activity } \\
\text { Change } \\
50 \mu \mathrm{M}\end{array}$ & $\begin{array}{c}\% \text { Activity } \\
\text { Change } \\
100 \mu \mathrm{M}\end{array}$ & $\begin{array}{c}\% \text { Activity } \\
\text { Change } \\
250 \mu \mathrm{M} \\
\end{array}$ & $\begin{array}{c}\text { \% Activity } \\
\text { Change } \\
500 \mu \mathrm{M}\end{array}$ \\
\hline CDK5/p25 & 2 & -8 & -22 & -46 & -73 & -85 \\
\hline CDK5/p35 & -3 & -14 & -35 & -57 & -73 & -84 \\
\hline ERK1 & 1 & 0 & -2 & -15 & -35 & -54 \\
\hline GSK3 $\beta$ & -1 & 3 & 6 & 15 & 27 & 40 \\
\hline
\end{tabular}

Likewise, the profiling data for p5-WT against CDK5/p35 showed moderate to strong inhibition of $\mathrm{CDK} 5 / \mathrm{p} 35$ activity with increasing compound concentration (Supplementary Table 4). At $250 \mu \mathrm{M}$ concentration of this peptide, the CDK5/p35 activity was inhibited by $53 \%$ compared to control. An $\mathrm{IC}_{50}$ value of $217 \mu \mathrm{M}$ was generated (using a graph of $\log$ inhibitor versus normalized response with variable slope with the Prism software) for this compound against CDK5/p35 (Fig. 2). These findings reveal that p5-WT inhibited both $\mathrm{p} 25$ and $\mathrm{p} 35$ activation of CDK5 fairly equally.

The profiling data for compound p5-WT against ERK1 showed much weaker inhibition of ERK1 phosphotransferase activity with increasing compound concentration (Fig. 2). At $500 \mu \mathrm{M}$ concentration of p5-WT, the ERK1 activity was inhibited by only $25 \%$ compared to control. An $\mathrm{IC}_{50}$ value of $1322 \mu \mathrm{M}$ was generated (using a graph of log inhibitor versus normalized response with variable slope with the Prism software) for this peptide against ERK1 (Fig. 2). The profiling data for $\mathrm{p} 5$-WT against GSK3 $\beta$ showed no inhibition of GSK $3 \beta$ phosphotransferase activity with increasing compound concentration (Fig. 2). At $500 \mu \mathrm{M}$ concentration of this peptide, the GSK3 $\beta$ phosphotransferase activity was slightly activated by $24 \%$ compared to control.

The profiling data for the mutated peptide p5-MT against CDK5/p25 showed strong to potent inhibition of CDK5/p25 phosphotransferase activity with increasing compound concentration (Supplementary Table 7). At $100 \mu \mathrm{M}$ concentration of this peptide, the
CDK5/p25 phosphotransferase activity was inhibited by $46 \%$ compared to control. An $\mathrm{IC}_{50}$ value of $119 \mu \mathrm{M}$ was generated (using a graph of log inhibitor versus normalized response with variable slope with the Prism software) for this compound against CDK5/p25 (Fig. 3).

The profiling data for compound p5-MT against CDK5/p35 showed strong to potent inhibition of CDK5/p35 phosphotransferase activity with increasing compound concentration (Supplementary Table 8). At $100 \mu \mathrm{M}$ concentration of compound p5-MT, the CDK5/p35 phosphotransferase activity was inhibited by $57 \%$ compared to control. An $\mathrm{IC}_{50}$ value of $83 \mu \mathrm{M}$ was generated (using a graph of $\log$ inhibitor versus normalized response with variable slope with the Prism software) for this compound against CDK5/p35 (Fig. 3).

The profiling data for p5-MT against ERK1 showed weak to moderate inhibition of ERK1 phosphotransferase activity with increasing compound concentrations (Supplementary Table 9). At $500 \mu \mathrm{M}$ concentration of compound p5-MT, the ERK1 activity was inhibited by $54 \%$ compared to control. An $\mathrm{IC}_{50}$ value of $425 \mu \mathrm{M}$ was generated (using a graph of $\log$ inhibitor versus normalized response with variable slope with the Prism software) for this compound against ERK1 (Fig. 3). The profiling data for p5-MT against GSK3 $\beta$ showed weak activation of this kinase with increasing compound concentration (Fig. 3). At $500 \mu \mathrm{M}$ concentration of this peptide, the GSK3 $\beta$ phosphotransferase activity was activated by $40 \%$ compared to control. 


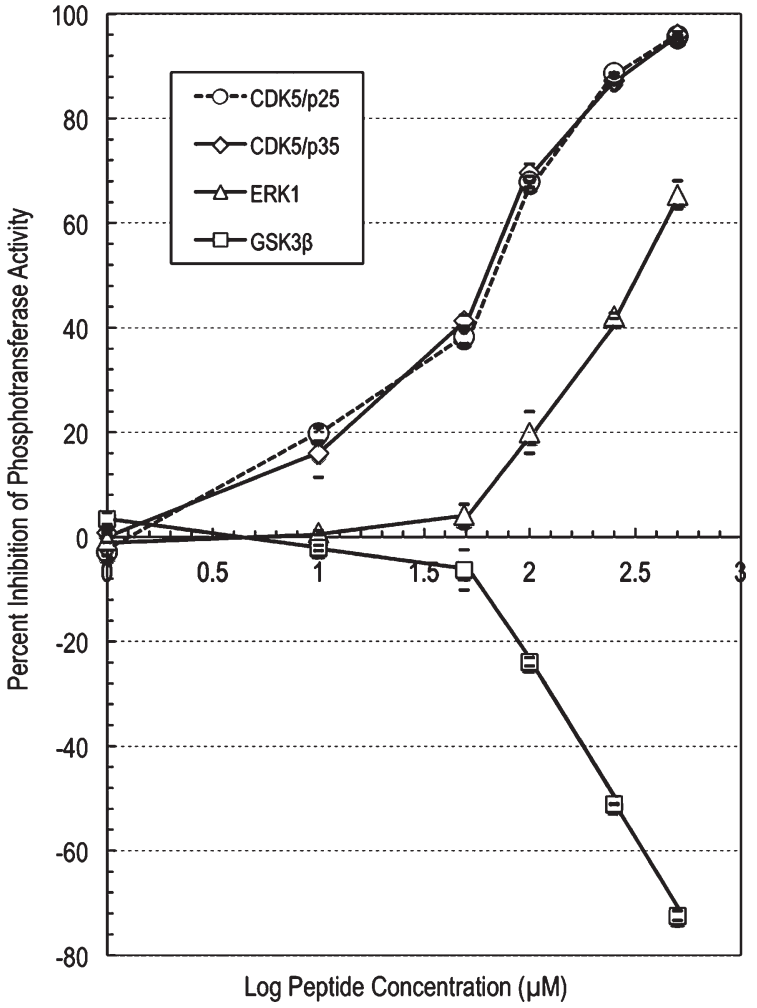

Fig. 2. p5-WT peptide concentration-dependent effects on the phosphotransferase activities of CDK5, ERK1 and GSK3 $\beta$. IC 50 determination for compound p5-WT against protein kinases. A graph of $\log$ inhibitor versus normalized response with variable slope was generated using the Prism software. The graph showed increased inhibition of the phosphotransferase activities of CDK5 and ERK1, and increased stimulation of GSK3 $\beta$ with increasing compound concentration. The $\mathrm{IC}_{50}$ value for compound $\mathrm{p} 5$-WT against $\mathrm{CDK} 5 / \mathrm{p} 25$ was determined to be $169 \mu \mathrm{M}$, the $\mathrm{IC}_{50}$ value for compound $\mathrm{p} 5$-WT against CDK5/p35 was determined to be $217 \mu \mathrm{M}$, and the $\mathrm{IC}_{50}$ value for compound p5-WT against ERK1 was determined to be $1322 \mu \mathrm{M}$.

\section{CONCLUSION}

After the production of 78 mimetic peptides with single amino acid substitutions of the $\mathrm{p} 5$-WT sequence, the p5-MT peptide with a A24V replacement was determined to be slightly more potent in its inhibition of p25 and p35 stimulation of CDK5 phosphotransferase activity $\left(\mathrm{IC}_{50}=169\right.$ to $217 \mu \mathrm{M}$ for $\mathrm{p} 25$ and $\mathrm{p} 35$, respectively for $\mathrm{p} 5-\mathrm{WT} ; \mathrm{IC}_{50}=119$ to $83 \mu \mathrm{M}$ for $\mathrm{p} 25$ and $\mathrm{p} 35$, respectively for $\mathrm{p} 5-\mathrm{MT}$ ). The $\mathrm{p} 5$-WT and $\mathrm{p} 5$ MT were more extensively tested for their actions on the related proline-directed kinases ERK1 and GSK3 $\beta$, and ERK1 was modestly inhibited by the p5-MT peptide $\left(\mathrm{IC}_{50}=425 \mu \mathrm{M}\right)$ and to a lesser extent by the p5-WT peptide, and the phosphotransferase activity of GSK3- $\beta$ was weekly stimulated by these peptides.

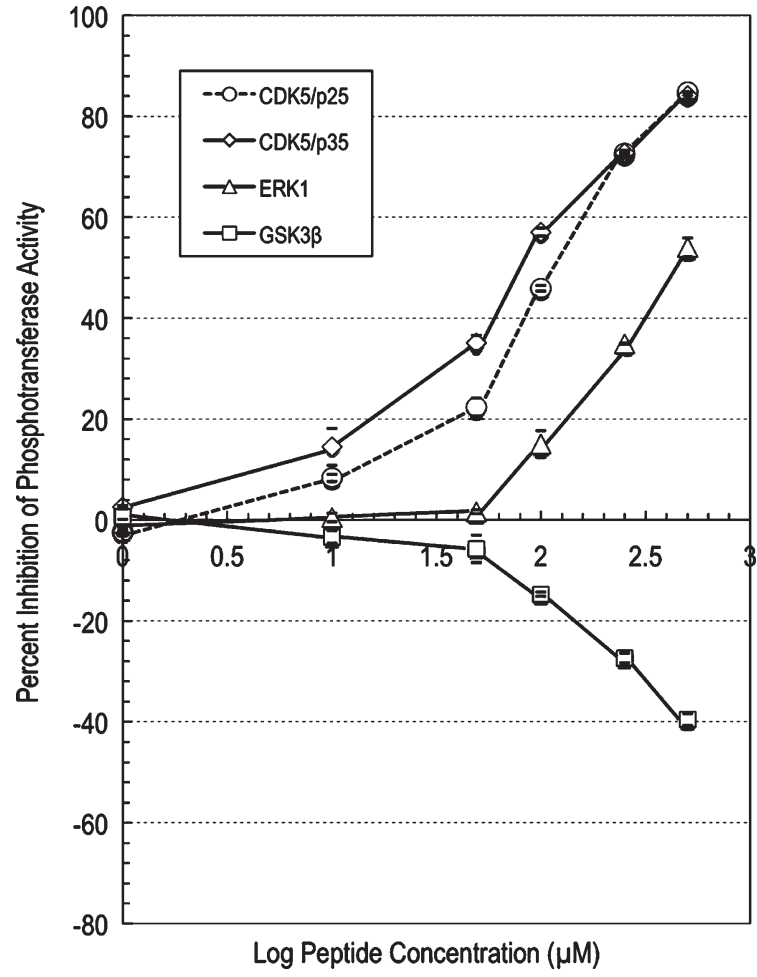

Fig. 3. p5-MT peptide concentration-dependent effects on the phosphotransferase activities of CDK5, ERK1, and GSK3 $\beta$. IC 50 determination for compound p5-MT against protein kinases. A graph of $\log$ inhibitor versus normalized response with variable slope was generated using the Prism software. The graph showed increased inhibition of the phosphotransferase activities of CDK5 and ERK1, and increased stimulation of GSK3 $\beta$ with increasing compound concentration. The $\mathrm{IC}_{50}$ value for compound $\mathrm{p} 5$-MT against CDK5/p25 was determined to be $119 \mu \mathrm{M}$, the $\mathrm{IC}_{50}$ value for compound $\mathrm{p} 5-\mathrm{MT}$ against CDK5/p35 was determined to be $83 \mu \mathrm{M}$, and the $\mathrm{IC}_{50}$ value for compound p5-MT against ERK1 was determined to be $425 \mu \mathrm{M}$.

\section{ACKNOWLEDGMENTS}

The authors thank Dr. Philip Grant for helpful discussions. This work was supported by the intramural research program of the U.S. National Institutes of Health (NIH), NINDS.

Authors' disclosures available online (http://j-alz. com/manuscript-disclosures/15-0412r2).

\section{SUPPLEMENTARY MATERIAL}

The supplementary material is available in the electronic version of this article: http://dx.doi.org/ 10.3233/JAD-150412. 


\section{REFERENCES}

[1] Shetty KT, Link WT, Pant HC (1993) cdc2-like kinase from rat spinal cord specifically phosphorylates KSPXK motifs in neurofilament proteins: Isolation and characterization. Proc Natl Acad Sci U S A 90, 6844-6848.

[2] Tsai LH, Delalle I, Caviness VS Jr, Chae T, Harlow E (1994) p35 is a neural-specific regulatory subunit of cyclin-dependent kinase 5. Nature 371, 419-423.

[3] Grant P, Pant HC (2002) Topographic regulation of kinase activity in Alzheimer's disease brains. J Alzheimers Dis 4 269-281

[4] Binukumar BK, Shukla V, Amin ND, Reddy P, Skuntz S, Grant P, Pant HC (2013) Topographic regulation of neuronal intermediate filaments by phosphorylation, role of peptidyl-prolyl isomerase 1: Significance in neurodegeneration. Histochem Cell Biol 140, 23-32.

[5] Pant HC, Veeranna (1995) Neurofilament phosphorylation. Biochem Cell Biol 73, 575-592.

[6] Cheng K, Ip NY (2003) Cdk5: A new player at synapses. Neurosignals 12, 180-190.

[7] Ohshima T, Mikoshiba K (2002) Reelin signaling and Cdk5 in the control of neuronal positioning. Mol Neurobiol 26, 153 166.

[8] Ohshima T, Ward JM, Huh CG, Longenecker G, Veeranna, Pant HC, Brady RO, Martin LJ, Kulkarni AB (1996) Targeted disruption of the cyclin-dependent kinase 5 gene results in abnormal corticogenesis, neuronal pathology and perinatal death. Proc Natl Acad Sci U S A 93, 11173-11178.

[9] Lee MS, Tsai LH (2003) Cdk5: One of the links between senile plaques and neurofibrillary tangles? J Alzheimers Dis 5, 127-137.

[10] Lim AC, Qi RZ (2003) Cyclin-dependent kinases in neural development and degeneration. J Alzheimers Dis 5, 329-335.

[11] Monaco EA, 3rd (2004) Recent evidence regarding a role for Cdk5 dysregulation in Alzheimer's disease. Curr Alzheimer Res 1, 33-38
[12] Monaco EA, 3rd, Vallano ML (2005) Role of protein kinases in neurodegenerative disease: Cyclin-dependent kinases in Alzheimer's disease. Front Biosci 10, 143-159.

[13] Patrick GN, Zukerberg L, Nikolic M, de la Monte S, Dikkes P, Tsai LH (1999) Conversion of p35 to p25 deregulates Cdk5 activity and promotes neurodegeneration. Nature 402, 615622.

[14] Kesavapany S, Li BS, Pant HC (2003) Cyclin-dependent kinase 5 in neurofilament function and regulation. Neurosignals 12, 252-264.

[15] Shukla V, Skuntz S, Pant HC (2012) Deregulated Cdk5 activity is involved in inducing Alzheimer's disease. Arch Med Res 43, 655-662.

[16] Zheng YL, Amin ND, Hu YF, Rudrabhatla P, Shukla V, Kanungo J, Kesavapany S, Grant P, Albers W, Pant HC (2010) A 24-residue peptide (p5), derived from p35, the Cdk5 neuronal activator, specifically inhibits Cdk5-p25 hyperactivity and tau hyperphosphorylation. J Biol Chem 285, 3420234212.

[17] Tsai LH, Lee MS, Cruz J (2004) Cdk5, a therapeutic target for Alzheimer's disease? Biochim Biophys Acta 1697, 137-142.

[18] Wu PC, Tai MH, Hu DN, Lai CH, Chen YH, Wu YC, Tsai CL, Shin SJ, Kuo HK (2008) Cyclin-dependent kinase inhibitor roscovitine induces cell cycle arrest and apoptosis in rabbit retinal pigment epithelial cells. J Ocul Pharmacol Ther 24, 25-33.

[19] Yan Z, Chi P, Bibb JA, Ryan TA, Greengard P (2002) Roscovitine: A novel regulator of P/Q-type calcium channels and transmitter release in central neurons. J Physiol 540, 761-770.

[20] Zhang B, Tan VB, Lim KM, Tay TE, Zhuang S (2007) Study of the inhibition of cyclin-dependent kinases with roscovitine and indirubin-3'-oxime from molecular dynamics simulations. J Mol Model 13, 79-89.

[21] Amin ND, Albers W, Pant HC (2002) Cyclin-dependent kinase 5 (cdk5) activation requires interaction with three domains of p35. J Neurosci Res 67, 354-362. 